DOI: http://dx.doi.org/10.33846/ghs5405

\title{
Pengaruh Penyuluhan Tentang Kesehatan Reproduksi Berbasis Audio Visual Terhadap Tingkat Pengetahuan Siswi Sma Negeri 7 Kecamatan Leihitu Kabupaten Maluku Tengah Tahun 2019
}

Epi Dusra (koresponden)

(IImu Kesehatan Masyarakat; STIKes Maluku Husada; dusraephy@gmail.com)

Jarna Suneth

(IImu Kesehatan Masyarakat; STIKes Maluku Husada: jarnasuneth@gmail.com)

Milda Wael

(IImu Kesehatan Masyarakat; STIKes Maluku Husada: mildawael@gmail.com)

Jumra Trilla

(IImu Kesehatan Masyarakat; STIKes Maluku Husada; jumratrilla@gmail.com)

\begin{abstract}
ABSTRAK
Kesehatan reproduksi adalah keadaan yang menunjukan kondisi kesehatan fisik, mental, dan sosial seseorang dihubungkan dengan fungsi dan proses reproduksinya termasuk didalamnya tidak memiliki penyakit atau kelainan yang mempengaruhi kegiatan reproduksi tersebut. Dampak dari ketidakpahaman remaja mengenai kesehatan reproduksi dapat menjerumuskan mereka kedalam masalah-masalah kesehatan reproduksi. Salah satu program pendidikan kesehatan yang dilakukan yaitu dengan cara memberikan penyuluhan. Penyuluhan berbasis multimedia dapat menstimulasikan objek nyata kedalam bentuk animasi pada organ reproduksi manusia dengan maksud agar para remaja dapat lebih mudah memahami dan menerima informasi yang tepat tentang kesehatan reproduksi. Penelitian ini bertujuan untuk melihat pengaruh penyuluhan tentang kesehatan reproduksi berbasis audio visual terhadap tingkat pengetahuan siswi SMA Negeri 7 Kecamatan Leihitu Kabupaten Maluku Tengah Tahun 2019. Penelitaan ini merupakan penelitian kuantitatif yang menggunakan metode Quasi Experimental dengan desain penelitian One Group Pretest Postest. Sampel penelitian berjumlah 22 responden menggunakan Total Sampling alat ukur menggunakan kuisioner. Analisa data meliputi analisis univariat dan analisis bivariat dengan menggunakan uji wilcoxon. Hasil penelitian setelah dilakukan penyuluhan tentang kesehatan reproduksi berbasis audio visual pengetahuan siswi mengalami peningkatan pengetahuan. Kesimpulan penyuluhan tentang kesehatan reproduksi berbasis audio visual berpengaruh terhadap tingkat pengetahuan siswi SMA Negeri kecamatan Leihitu Kabupaten Maluku Tengah Tahun 2019.
\end{abstract}

Kata Kunci: kesehatan reproduksi; penyuluhan berbasis audio visual; pengetahuan

\section{PENDAHULUAN}

\section{Latar Belakang}

Kesehatan reproduksi, sama halnya dengan kesehatan pada umumnya, adalah hak setiap manusia. Menurut WHO (2014) kesehatan reproduksi adalah keadaan yang menunjukan kondisi kesehatan fisik, mental, dan sosial seseorang dihubungkan dengan fungsi dan proses reproduksinya termasuk didalamnya tidak memiliki penyakit atau kelainan yang mempengaruhi kegiatan reproduksi tersebut. ${ }^{(1)}$

Sepertiga penduduk Indonesia adalah remaja sehingga kesehatan reproduksi remaja tetap menjadi salah satu prioritas program kesehatan di Indonesia. Masa remaja merupakan masa transisi dari masa anak-anak menuju dewasa. Masa ini merupakan periode persiapan menuju dewasa yang akan melewati beberapa perkembangan penting dalam hidup (2)

Remaja adalah penduduk dalam rentang usia 10-19 tahun, menurut peraturan mentri kesehatan RI Nomor 25 tahun 2014, remaja adalah penduduk dalam rentang usia 10-18 tahun dan menurut Badan Kependudukan Dan Keluarga Berencana (BKKBN) rentang usia remaja adalah 10-24 tahun dan belum menikah. (1) Kesehatan reproduksi remaja mempunyai makna suatu kondisi sehat yang menyangkut sistem reproduksi (fungsi, komponen dan proses) yang dimiliki oleh remaja baik secara fisik, mental, sosial dan spiritual. (1), (3)

Sekitar 21 juta remaja perempuan yang berumur 15-18 tahun di Negara berkembang, mengalami kehamilan setiap tahun dan hampir setengah kehamilan tersebut $(49 \%)$ merupakan kehamilan yang tidak diinginkan. Kehamilan tersebut salah satunya disebabkan oleh adanya perilaku seks menyimpang yang cenderung mengalami peningkatan setiap tahunnya. Pada 18 negara 
diantaranya yaitu : Afrika (40\%), Thailand (47\%), Amerika Latin dan Karibia (29\%), dan lain sebagainya. Terjadi peningkatan kasus kehamilan usia remaja di daerah perkotaannya. Presentase perempuan melahirkan pertama kali $<18$ tahun, lebih dari $83 \%$ dari populasi pada daerah tersebut. Akibat perilaku seks menyimpang pada remaja yang menyebabkan kehamilan yang tidak diinginkan dapat mendorong remaja untuk melakukan aborsi. (4)

Kesehatan reproduksi remaja meliputi kebersihan organ-organ reproduksi dan cara pemeliharaannya. Organ reproduksi merupakan daerah tertutup dan berlipat sehingga lebih mudah untuk berkeringat, lembab, dan kotor. Cara pemeliharaan organ reproduksi yang tidak tepat dalam menjaga kebersihan genitalia, seperti mencucinya dengan air kotor, memakai pembilas secara berlebihan, menggunakan celana yang tidak menyerap keringat, jarang mengganti celana dalam, dan tak sering mengganti pembalut dapat menjadi pencetus timbulnya infeksi. Dampak dari ketidakpahaman remaja mengenai kesehatan reproduksi dapat menjerumuskan meraka dalam masalah-maslah kesehatan reproduksi. Sehingga perlu dilakukan pendidikan tentang kesehatan reproduksi remaja untuk meningkatkan pengethauan mereka dengan tepat mengenai kesehatan reproduksi. Salah satu program pendidikan kesehattan yang dilakukan yaitu dengan cara memberikan penyuluhan. ${ }^{(5)}$

Berdasarkan hasil wawancara yang peneliti lakukan terhadap 10 orang siswi, 7 diantaranya menjawab dengan ragu-ragu dan tidak mengetahui dengan benar cara pemeliharaan organ reproduksi yang benar dan belum memahami tentang kesehatan reproduksi. Berdasarkan hasil wawancara tersebut, peneliti tertarik untuk melakukan penelitian terkait "Pengaruh Penyuluhan Tentang Kesehatan Reproduksi Berbasis Audio Visual Terhadap Tingkat Pengetahuan Siswi SMA Negeri 7 Kecamatan Leihitu Kabupaten Maluku Tengah Tahun 2019".

\section{Tujuan Penelitian}

Penelitian ini bertujuan untuk melihat pengaruh penyuluhan tentang kesehatan reproduksi berbasis audio visual terhadap tingkat pengetahuan siswi SMA Negeri 7 Kecamatan Leihitu Kabupaten Maluku Tengah Tahun 2019.

\section{METODE}

Penelitian ini merupakan penelitian Quasi eksperimental (interventional) dengan metode one group pretest dan posttest design, yaitu menilai tingkat pengetahuan siswi SMA Negeri 7 Kecamatan Leihitu Kabupaten Maluku Tengah sebelum diberikan penyuluhan dan sesudah diberikan penyuluhan. Waktu penelitian dilaksanakan selama 1 bulan (09 Agustus-09 September 2019).

Tabel 1. Item Total Statistics

\begin{tabular}{|c|c|c|c|}
\hline Item & Corrected Item Total Correlation & $\mathrm{r}$ Tabel $(0,361)$ & Keterangan \\
\hline P1 & 0,109 & 0,361 & Tidak Valid \\
\hline P2 & 0,490 & 0,361 & Valid \\
\hline P3 & 0,692 & 0,361 & Valid \\
\hline P4 & 0,763 & 0,361 & Valid \\
\hline P5 & 0,763 & 0,361 & Valid \\
\hline P6 & 0,365 & 0,361 & Valid \\
\hline P7 & 0,276 & 0,361 & Tidak Valid \\
\hline P8 & 0,000 & 0,361 & Tidak Valid \\
\hline P9 & 0,575 & 0,361 & Valid \\
\hline P10 & 0,575 & 0,361 & Valid \\
\hline P11 & 0,000 & 0,361 & Tidak Valid \\
\hline P12 & 0,121 & 0,361 & Tidak Valid \\
\hline P13 & 0,402 & 0,361 & Valid \\
\hline P14 & 0,825 & 0,361 & Valid \\
\hline P15 & 0,528 & 0,361 & Valid \\
\hline P16 & 0,490 & 0,361 & Valid \\
\hline P17 & 0,692 & 0,361 & Valid \\
\hline P18 & 0,763 & 0,361 & Valid \\
\hline P19 & 0,763 & 0,361 & Valid \\
\hline P20 & 0,365 & 0,361 & Valid \\
\hline
\end{tabular}


Setelah pengambilan data dilakukandan data diperoleh, maka selanjutnya dilakukan pengolahan data yang meliputi beberapa bagian yaitu: editing, coding, dan tabulating. Setelah data diolah, selanjutnya dilakukan analisis data dengan mengunakan software computer SPSS. Adapun analisis yang digunakan yaitu: analisis univariat dan bivariat dengan mengunakan uji statistic wilcoxon dengan kemaknaan $(\alpha=0,05)$.

\section{HASIL}

\section{Karakteristik Responden}

Tabel 2. Distribusi Responden Berdasarkan Umur Siswi Kelas XI SMA Negeri 7 Leihitu

\begin{tabular}{|c|c|c|}
\hline Umur & $\mathrm{n}$ & $\%$ \\
\hline 15 & 8 & 36,4 \\
\hline 16 & 11 & 50,0 \\
\hline 17 & 3 & 13,6 \\
\hline Total & 22 & 100,0 \\
\hline
\end{tabular}

Berdasarkan tabel 2, sebagian besar responden berusia 16 tahun $(50,0 \%)$.

\section{Analisa Univariat}

Analisa univariat mendeskripsikan pengetahuan responden sbelum diberikan penyuluhan tentang kesehatan reproduksi dan sesudah diberikan penyuluhan tentang kesehatan reproduksi.

Tabel 3. Distribusi Responden Berdasarkan Tingkat Pengetahuan pada Siswi SMA Negeri 7 Leihitu

\begin{tabular}{|c|c|c|c|c|c|c|}
\hline Pengetahuan & \multicolumn{3}{|c|}{ Pretest } & \multicolumn{3}{|c|}{ Posttest } \\
\cline { 2 - 3 } & $\mathrm{n}$ & $\%$ & Mean & $\mathrm{n}$ & $\%$ & Mean \\
\hline Baik & & & & 22 & 100 & \multirow{2}{*}{12,86} \\
\hline Cukup & 16 & 72,7 & \multirow{2}{*}{8,73} & & & \\
\hline Kurang & 6 & 27,3 & & & & \\
\hline Total & 22 & & & 22 & 100 & \\
\hline
\end{tabular}

Tabel 3 menggambarkan bahwa pengetahuan siswi sebelum diberikan penyuluhan tentang kesehatan reproduksi yaitu sebanyak 16 responden berpengetahuan cukup $(72,7 \%)$ dan 6 respondenberpengetahuan kurang $(27,3 \%)$. Setelah diberikan penyuluhan tentang kesehatan reproduksi berbasis audio visual, pengetahuan responden meningkat menjadi lebih baik (100\%).

\section{Analisa Bivariat}

Analisa bivariat dilakukan untuk menguji hipotesis pengaruh penyuluhan tentang kesehatan reproduksi berbasis audio visual terhadap tingkat pengetahuan. Analisa ini dilihat dari seberapa besar pengaruh penyuluhan tentang kesehatan reproduksi berbasis audio visual terhadap tingkat pengetahuan, dengan menganalisa hasil pengetahuan sebelum dan sesudah diberikan penyuluhan. Jenis analisa yang digunakan adalah uji statistic Wilcoxon. Sebelum dilakukan analisis data peneliti melakukan uji normalitas data terlebi dahulu.

$\underline{\text { Uji normalitas }}$

Tabel 4. Hasil Uji Normalitas Data Menggunakan Shapiro-Wilk

\begin{tabular}{|c|c|c|c|c|c|c|}
\hline Pengetahuan & Statistik & Df & Min & Max & Sig & Ket \\
\hline Pretest & 783 & 22 & 3 & 11 & 000 & Tidk Normal \\
\hline Posttest & 807 & 22 & 12 & 14 & 001 & Tidak Normal \\
\hline
\end{tabular}

Berdasarkan tabel 4 dapat diketahui bahwa telah diperoleh hasil nilai kemaknaan untuk dua kelompok data adalah $<0,05$. Sehingga dapat diambil kesimpulan bahwa ddistribusi kedua kelompok data adalah tidak normal. Maka uji non parametric yang digunakan adalah uji Wilcoxon. 


\section{$\underline{\text { Uji Wilcoxon }}$}

Tabel 5. Hasil Analisis Uji WilcoxonPengaruh Penyuluhan Tentang Kesehatan Reproduksi Berbasis Audio Visual Terhadap Tingkat Pengetahuan Siswi SMA Negeri 7 Kecamatan Leihitu Kabupaten Maluku Tengah Tahun 2019

\begin{tabular}{|c|c|c|c|}
\hline Pengetahuan & $\mathrm{N}$ & Median & $\rho$ value \\
\cline { 1 - 3 } Pretest & 22 & 9,00 & 000 \\
\hline Posttest & 22 & 13,00 & \\
\hline
\end{tabular}

Berdasarkan hasil uji statistik pada tabel 5 dapat diketahui bahwa ada perbedaan antara nilai pretest dan posttest. Dengan diperoleh nilai $\rho$ Value $=0,000$ lebih kecil dari $0,05(0,000<0,05)$ sehingga dapat disimpulkan bahwa Ha diterima dan $\mathrm{H}_{0}$ ditolak yang artinya bahwa penyuluhan tentang kesehatan reproduksi berbasis audio visual berpengaruh terhadap pengetahuan siswi SMA Negeri 7 Kecamatan Leihitu Kabupaten Maluku Tengah.

\section{PEMBAHASAN}

Pengetahuan siswi tentang kesehatan reproduksi sebelum diberikan penyuluhan adalah 6 $(27,3 \%)$ orang siswi memiliki pengetahuan yang kurang dan 16 (72,7\%) siswi memiliki pengetahuan cukup. Pengetahuan merupakan hasil " tahu " penginderaan manusia terhadap objek tertentu. Penginderaan ini terjadi melalui panca indra manusia yaitu indra penglihatan, pendengaran, penciuman, rasa dan raba. Sebagian besar pengetahuan manusia diperoleh melalui mata dan telinga (Notoatmodjo, 2007). Pengetahuan siswi tentang kesehatan reproduksi setelah diberikan penyuluhan tentang kesehatan reproduksi $100 \%$ dari total nilai tertinggi. Nilai yang didapat setelah diberikan penyuluhan tentang kesehatan reproduksi lebih besar dari nilai sebelum diberikan intervensi tentang penyuluhan kesehatan reproduksi. Hal terebut menunjukan bahwa terdapat peningkatan pengetahuan setelah diberikan intervensi.

hasil penelitian didapatkan nilai $p>0,05$ yang berarti tidak terdapat perbedaan yang signifikan terhadap pengetahuan remaja sebelum dan sesudah diberikan pendidikan kesehatan. Hasil penelitian ini menggunakan uji statistic dengan uji Wilcoxon dengan nilai signifikan $(p=0,000<0,05)$ sehingga dapat peneliti simpulkan bahwa $\mathrm{H}_{\mathrm{a}}$ diterima dan $\mathrm{H}_{0}$ ditolak yang artinya bahwa penyuluhan berasis audio visual berpengaruh terhadap tingkat pengetahuan siswi SMA Negeri 7 Leihitu Kabupaten Maluku Tengah. Masa remaja awal mempunyai resiko tinggi melakukan hubungan seksual pranikah. Oleh karena itu, masa yang paling tepat untuk memberikan pendidikan kesehatan reproduksi adalah pada masa remaja awal. Pendidikan kesehatan merupakan salah satu cara yang efektif untuk meningkatkan pengetahuan remaja tentang kesehatan reproduksi. Pendidikan kesehatan dapat dilakukan dengan beberapa metode, salah satu metode pendidikan kesehatan yang dapat digunakan yaitu metode ceramah. Ceramah adalah pidato yang disampaikan oleh pembicara didepan sekelompok pendengar, metode ini baik untuk sarana yang berpendidikan tinggi maupun berpendididkan rendah. Metode ceramah merupakan cara penyajian materi pembelajaran melalui penuturan secara lisan. Keunggulannya dari metode tersebut adalah baik diterapkan pada sasaran yang berpendidikan tinggi maupun rendah, tidak memperlukan persiapan yang rumit cukup menyiapkan ruang kelas serta tempat duduk untuk audien kegiatan sudah bisa dilaksanakan. ${ }^{(6)}$

Penyuluhan kesehatan merupakan suatu kegiatan usaha yang menyampaikan pesan kesehatan kepada masyarakat, kelompok atau individu tertentu dengan harapan bahwa dengan adanya pesan tersebut individu atau kelompok tertentu dapat memperoleh pengeahuan tentang kesehatan tersebut. ${ }^{(7)}$

Menurut asumsi peneliti diketahui bahwa dari hasil penelitian diaatas dapat diketahui bahwa terdapat pengaruh yang signifikan setelah diberikaan intervensi penyuluhan tentang kesehatan reproduksi pada siswi SMA Negeri 7 Leihitu dengan nilai $p$-value yaitu 0,000. Dalam penelitian ini didapatkan informasi bahwa adanya perbedaan yang signifikan terhadap peningkatan pengetahuan siswi SMA Negeri 7 Leihitu tentang kesehatan reproduksi sejalan dengan uji statistik.

\section{KESIMPULAN}

Sebelum diberikan penyuluhan tentang kesehatan reproduksi berbasis audio visual, pengetahuan siswi SMA Negeri 7 Kecamatan Leihitu Kabupaten Mauku Tengah berda dalam kategori cukup. Setelah diberikan penyuluhan tentang kesehatan reproduksi berbasis audio visual, pengetahuan siswi SMA Negeri 7 Kecamatan Leihitu Kabupaten Maluku Tengah berada dalam 
kategori baik. Penyuluhan tentang kesehatan reproduksi berbasis audio visual berpengaruh terhadap tingkat pengetahuan siswi SMA Negeri 7 Kecamatan Leihitu Kabupaten Maluku Tengah.

\section{DAFTAR PUSTAKA}

1. BKKBN. Data survei Kesehatan Reproduksi Indonesia. Jakarta. 2002.

2. Masyudi dan Maulida F. M. 2017. Kesehatan reproduksi remaja putri di SMA Negeri 2 Takengon.Jurnal serambi Sumatera. Vol. V, No.1

3. Darma MYS dan F FA. 2017. Hubungan Pengetahuan Vulva Hygiene, Stress Dan Pola Makan Dengan Kejadian Infeksi Flour Albus (Keputihan) Pada Remaja Siswi SMA N 6 Kendari 2017. Jurnal ilmiah mahasiswa kesehatan masyarakat. Vol 2 No.6

4. Dewi R, Nani Y, Cece S.I. Analisis Faktor-Faktor yang berhubungan dengan Perilaku Seks Pranikah Mahasiswa Kos-Kosan di Kelurahan Lalolara Tahun 2016. JIMKESMAS Jurnal IImiah Mahasiswa Kesehatan Masyarakat Vol. 2/No.5/ Januari 2017; ISSN250-731X

5. Ratna D.P, Winda T.U, Dian I.A, Muhammad A. Peningkatan Kesehatan Reproduksi Remaja Putri Melalui Penyuluhan dan Simulasi Menjaga Kebersihan Alat Kelamin Luar Wanita Di SMA Muhammadiyah 2 Bandarlampung. Penyuluhan dan Simulasi Menjaga Kebersihan Alat Kelamin Luar Wanita.

6. Delli Y, lyos S. Pengaruh Pendidikan Kesehatan Ceramah terhadap Tingkat Pengetahuan Remaja tentang Kesehatan Reproduksi di SMP Negeri 2 Tanjungsari Sumedang. Jurnal Keperawatan Komprehensif Vol. 3 No. 1, Januari 2017: 45-51

7. Zainudin S. 2017. Pengaruh Penyuluhan Kesehatan Terhadap Pengetahuan Remaja Tentang Penyakit Menular Seksual Di SMP N 5 Bangkala Kabupaten Jeneponto. (Skripsi) Universitas Islam Negeri Makassar. 